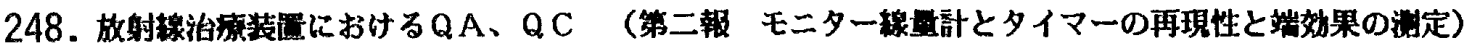

京大病院 O岡田 孝 野原弘基 京都市立病院 石山 忍 大阪医大病院 植西信之 京都拊立病院 増田毒一 加藤康雄 武部義行 関西医大病院 西村茂樹 松田 茂 滋皿成人病センター 小野武志 京都第二赤十字病院 过 秀害 国立京 都病院 松山隆一住友病院 田中庯二 聯賀医大病院 雄川恭行 近藤康雄 甲賀病院 上村久司 桂病院 西村正司

[目的］放射線治療声置のQA、QCは、治㙩を行う上で重要である。そこで今回我々は、各施設に拪けるモニター線量 計の再現性(LINAC)、タイマーの再現性と端勃果(COBALT)の测定を行い、放射線治療システム研究会、治療枝置研究委員

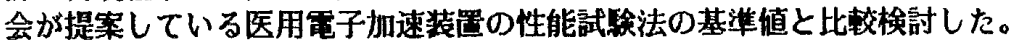

[方法］ (1)モニター線量計の再現性については、ウォームアップのカウント数、測定間隔、電源投入後测定開始までの 時間を各々変化させて10回测定し算出した。(2)夕イマーの再現性は、30秒、60秒、120秒の各々について 10 回测定し算出した。(3)夕イマー端劣果は、S C D を变え、線量率を变化させて測定した。

[結果] (1)8施設中7施設において、再現性の基準値 $0.5 \%$ 满たしていた。(2)全て（4施設）の施設に押いて、基準 值を满たしていた。(3)装置の種類によっで-3.03〜1.56cGyであった。線畺率の変化によって、かなり値が连った。

\section{9. 線量モニタシステムの照射野形状による依存性}

東京医科大学病院 ○久保浩一 横山公一 石上信雄 野呂正志 河本敦夫 福田朋好 澤枅久嘉

[目的] 当施設のリニアックについて、線量モニタシステムの性能試験法として提案されている各項目について調へた結果 誤差が問題になった項目のうち、今回は、主として線量モニタに対する上下段可動絞りの配置の違いに起因する照射野形状 による依存性について詳しく調べ、補正方法を検討した。

[方法] ML-20M、LMR-4のX線(10MV、AMV)を用いて、面皘・周囲長比(A/P)を1.5 3.5cm(7段階)としたとき、各A/Pについて、 可動コリメータの上段絞りの開度(X)に対する、モ二夕単位当たりの校正点吸収線量(D/MU)の变化を調べた。次に、X・P/4A に対して、正方形の吸収線量で規格化したD/MUをフロットし、これらの曲線を基に任意のA/Pに適用できる補正曲線を得た。 [結果] A/Pを一定にしたとき、上段较りを閉じていくと校正点吸収線量は急に減少していくが、下段较りを閉じていった 場合は土1\%以内に収まる。これは両葫苦とも同じである。上段较りを较ったときは、今回求めた補正曲線から任意の照射野 について補正が可能である。下段鉸りを较ったときは補正は必要ないので、できるだけ下段絞りを绞って使用するのがよい。

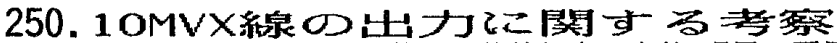

O武田均,玫島利男, 石風呂 実, 斎藤温已, 石見 義夫 広島大学医学部附属病院放射線部

目的 10MVX線を用いて,Upper JowとLower Jowで交互に 照射野3-35cmの矩形照射 野を作り,Fieid facterの変化について検討した。

方法 日常用いている area/perimeaterを基準にして, Upper JowとLower Jowで作 られる各々のField facter及び，同じ深さでのT P Rを测定した。

結果 T P Rに関しては,A/P 法による等価正方形のT P Rに1\%以内で一致した。 (Upper Jow,Lower Jow) $35 \times 3 \mathrm{~cm}$ と $3 \times 35 \mathrm{~cm}$ DField facterにおいて4\%以上 の違いを生じた。

251．電睢箱線量計の床面常設による放射線治療装置の缐管理 栃木県済生会宇都宮病院 放的線科 ○闦口 浩三 中沢武夫梅野一雄

离エネルギ一放射線治療装要に於けるモ二タ線量計の校正は、出力線量安定をみるため週に一回以上行う事が望ま

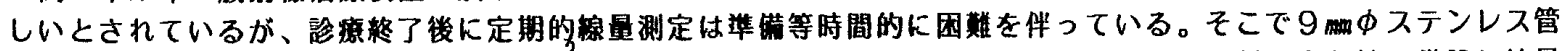

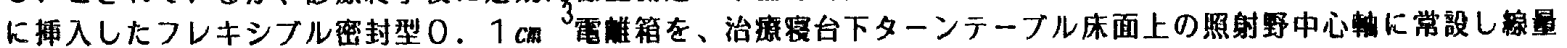
計と接続させ常庤简便に测定出来るようにし、空中照射線量测定から出力線量変化を確認することを試みた。

每日. 装置を安定させる謂整时を利用して、1 $0 \mathrm{MVX}$ 線の空中照射楾量を测定記䟿することにした。又、放射線

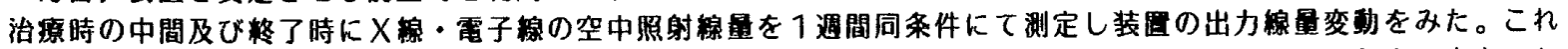
らから装置の出力線量変䖝を見ると $10 \mathrm{MVX}$ 線は安定した楾量が得られた。電子楾はそれぞれとも多少不安定であ り線量変軘があった。常設した電崔箱線量計を使用することにより简便に架中照射楾量测定から、出力湶量管理が可 能となり線量変功が大きく変化したとき、置のモ二タ線量計の校正を行うことにした。 